\title{
Determination of Cooperative Loan Funds Recipients Using Complex Proportional Assessment (COPRAS) Method
}

\author{
Syafrida Hafni Sahir ${ }^{1}$, Kersna Minan ${ }^{2}$, M Mesran $^{3}$, S Suginam ${ }^{3}$ \\ \{syafrida.hafnisahir@gmail.com\}

\begin{abstract}
${ }^{1}$ Department Of Business Economics, Universitas Medan Area, North Sumatera, Indonesia ${ }^{2}$ Department Of Business Economics, Universitas Harapan Medan, North Sumatera, Indonesia

${ }^{3}$ Department Of Computer Science, STMIK Budi Darma, North Sumatera, Indonesia
\end{abstract}

\begin{abstract}
Cooperative as a savings and loan business with legal status, has capacity in lending to members who voluntarily merged into membership and perform their duties as members of the cooperative. Loan disbursement in this case as a cooperative loan fund is a program expected by its members. But the main problem of the program, namely the occurrence of bad debts, namely obstacles encountered in credit repayment, or payment of installments by members. To avoid the occurrence of missteps in lending, decisionmakers are expected to use a decision support system capable of counting members applying for loan funds. These alternative calculations will evaluate the criteria that benefit the members in addition to analyzing the less favorable criteria. For that reason, the application of Complex Proportional Assessment (COPRAS) method is very appropriate in selecting fund of cooperative loan recipient.
\end{abstract}

Keywords: COPRAS, Cooperative Loan Funds, Loan Funds Recipients

\section{Introduction}

Cooperatives are organizations that have a membership with voluntary nature. Members of the cooperative are open to the public, anyone can join the membership. Each member is willing to accept membership responsibilities. As a people's economic institution, cooperatives have long been known in Indonesia. The most common cooperative in Indonesia is the Savings and Loans Cooperative. Members are incorporated in the savings and loan cooperatives, require members to make deposits Deposit Principal and Deposit Mandatory in addition to members can also do Voluntary Deposits. In reality that is often encountered in Savings and Loans cooperatives in Indonesia, members-only registers the ID Card only, in the form of ID cards but do not make deposits of all required deposits. In addition to the function of Cooperatives as Savings and Loans for members who joined, cooperatives also perform banking practices such as distributing credit to the community.

One of the factors why cooperatives are in demand by people who are members of cooperatives because the cooperative can make the channeling of loan funds allocated for the empowerment of both micro, small and medium enterprises. For credit channeling (credit) the cooperative should analyze the credit needs of its members. Criteria that prioritize the distribution of loan funds to the creditor must be set. As an organization of interest, the determination of a cooperative loan fund established by a cooperative has not been processed 
using a computerized system. There are still many cooperatives found in the determination of creditor recipients using manual processing, in this case not yet using decision support system. So often encountered constraints in terms of distribution, including bad credit. Bad credit is a jam of debt payments made by members. Bad credit will lead to repayment of member loans inhibited. Another problem that often faced, namely the assessment made by the leadership in deciding the recipient of loan funds is subjective, without considering criteria that affect the members in making credit payments. In addition, many other obstacles are encountered in connection with the channeling of cooperative loan funds.

To avoid the occurrence of constraints for creditors, cooperatives are expected to use decision-based support systems[1]. Decision support system aims to select accurately the alternatives of cooperative members who want to lend cooperative funds. If many members of the cooperative will borrow cooperative funds at the same time, then this system can conduct the selection of members based on predetermined conditions or criteria. In order for the results given decision support system more effective than a used method for processing. Some methods can be used in calculations to get the best decisions, such as the methods of ELECTRE, COPRAS, EXPROM II, CPI[2][3]. In the previous study, Attri (2013) conducted a study using the Preference Selection Index (PSI) method to determine the design life cycle stage of the production system [4]. Khorshidi in 2014 conducted a comparative analysis of TOPSIS and PSI methods in material selection [5]. In 2016, Papathanasiou conducts research in social sustainability in agriculture using TOPSIS and VIKOR[6]. From the explanation above, researchers intend to conduct research that aims to assist decision makers in support of decisions on the determination of recipients of loan funds cooperatives. It is expected that the results of this research will help the cooperative in deciding which cooperative members are entitled to receive loans effectively and more accurately.

\section{Theory}

\subsection{Cooperative}

Cooperatives are economic organizations that get the attention of the Indonesian government with legal status and as a whole is part of the national development effort. Another name is Koperasi Simpan Pinjam or known as KSP namely Credit Cooperative (Kopdit). International KSP is also called the Credit Union. According to Muhammad Hatta, known as the Father of Cooperatives, defines cooperatives as joint economic entities engaged in the economy, composed of voluntary economies voluntarily and on the basis of equality of rights and obligations of undertaking a business that aims to meet the needs of its members.

According to Law no. 17 of 2012 on Cooperatives stated cooperatives are legal entities established by individuals or legal entities cooperatives, with the separation of its members as assets to run the business capital. Under the law the level of cooperative consists of the primary cooperative, which is a cooperative founded by and consists of a person, and a secondary cooperative which is a cooperative established by and consisting of cooperatives..

\subsection{Decision Support System}

Decision support system is an information system intended for managers or management. The main uses of decision support systems are helping managers to support decisions, in 
which case managers have decisions, and to improve the accuracy of the results of decisions, managers can use a system [7][8]. The decision result of the decision support system will not absolute replace the manager's decision. The accuracy of the results of this decision supportbased system [9] is by using methods that can compare [10] alternatives to other alternatives on different criteria, known as Multiple Criteria Decision Making (MCDM) [11][12]. Among the methods found in popular decision support systems are TOPSIS, SAW, PROMETHEE[13][14]. TOPSIS is one of the methods in decision support systems that are able to compare positive ideal solutions with ideal Solutions [14]. When compared with SAW, TOPSIS method is more complex. SAW method is a very simple method that is easy to understand. PROMETHEE II, EXPROM II, PROMETHEE III, PROMETHEE IV [15][16].

\subsection{Complex Proportional Assessment (COPRAS) Method}

The COPRAS method was introduced by Zavadskas, Kaklauskas, and Sarka in 1994. The application of this method by comparing each alternative and determining the priority of each alternative based on conflicting criteria by considering the criteria weighting [17].

The COPRAS method used herein for the decision of the recipient of the cooperative loan fund by taking into account the criteria that are required in obtaining it by considering the weight of each interest. The COPRAS method distinguishes both positive (benefit) criteria and negative (cost) criteria, and both types of criteria are valued separately in the calculation process. The advantages of the COPRAS method in calculating alternative utility rates indicate the extent to which alternatives are taken for comparison.

This is the steps of COPRAS method[18][19]:

Step 1: Determine the decision matrix.

$$
\mathrm{D}=\begin{array}{r}
A_{1} \\
A_{2} \\
A_{3} \\
A_{m}
\end{array}\left[\begin{array}{ccccc}
X_{11} & X_{12} & X_{12} & \cdot & X_{1 n} \\
X_{21} & X_{22} & X_{23} & \cdot & X_{2 n} \\
X_{31} & X_{32} & X_{33} & \cdot & X_{3 n} \\
\cdot & \cdot & \cdot & \cdot & \cdot \\
X_{m 1} & X_{m 2} & X_{m 3} & \cdot & X_{m n}
\end{array}\right]
$$

Step 2: Perform normalized decision matrix.

The stages of normalizing this decision matrix aim to obtain dimensionless values from different criteria so that all alternatives can be compared.

$$
X_{i j}=\frac{X_{i j}}{\sum_{1=1}^{m} X_{i j}}
$$

Step 3: Calculates a normalized weighted matrix

$\mathrm{D}^{\prime}=d_{i j}=X_{i j} * W_{j}$

Step 4: Compute the maximizes and minimizes index

To maximizing index using the formula(4) and minimizing indexes by (5).

$S_{+i}=\sum_{j=1}^{k} d_{i j} j=1,2, \ldots \ldots \ldots, k$

$S_{-i}=\sum_{j=1}^{k} d_{i j} j=k+1, k+2 \ldots, n .$. 
Step 5: Calculate the relative significances $\left(Q_{i}\right)$

$Q_{i}=\mathrm{S}_{+\mathrm{i}}+\frac{\sum_{i=1}^{m} S_{-i}}{S_{-i} \sum_{\mathrm{i}=1}^{\mathrm{m}}\left(1 / S_{-i}\right)}$

Step 6: Determine the priority order of alternative.

$A^{*}=\left\{A_{i} \mid \max Q_{i}\right\}$

Step 7: Calculate the The quantitative utility (Ui)

$U_{i}=\frac{Q_{i}}{Q_{\max }} \cdot 100 \%$

Implementation of COPRAS will produce the best alternative that is an alternative that has a quantitative utility value is $100 \%$.

\section{Result \& Discussion}

The process undertaken by the cooperative in the selection of loan fund receipts requires the criteria that have been determined as a condition in the submission. These criteria are loan size, term, age, membership duration, payment, amount of deposits. Of the six criteria, there are the criteria of the advantages of long membership, payment, the number of deposits. Profit criterion intends the higher the value of the alternative owned then the assessment of the alternative will be better. Then there are the cost criteria, namely the amount of loan, time period, and age. The cost criterion aims, the smaller the alternative value the better the assessment results. Table 1 lists the criteria used in the processing using the COPRAS method.

Table 1: List of the Criteria

\begin{tabular}{lcl}
\hline \multicolumn{1}{c}{ Criteria } & Weighted & \multicolumn{1}{c}{ Type } \\
\hline Large Loans (Million) $\left(\mathrm{C}_{1}\right)$ & $25 \%$ & Cost \\
Term (Month) $\left(\mathrm{C}_{2}\right)$ & $15 \%$ & Cost \\
Age (Year)(C $)$ & $10 \%$ & Cost \\
Membership (Year) $\left(\mathrm{C}_{4}\right)$ & $25 \%$ & Benefit \\
Payment (Thousands) $\left(\mathrm{C}_{5}\right)$ & $15 \%$ & Benefit \\
Total Deposit (Million) $\left(\mathrm{C}_{6}\right)$ & $10 \%$ & Benefit \\
\hline
\end{tabular}

Table 2: Alternative match rating and criteria

\begin{tabular}{ccccccc}
\hline Alternative & $\mathrm{C}_{1}$ & $\mathrm{C}_{2}$ & $\mathrm{C}_{3}$ & $\mathrm{C}_{4}$ & $\mathrm{C}_{5}$ & $\mathrm{C}_{6}$ \\
\hline $\mathrm{A}_{1}$ & 22,5 & 2 & 35 & 1,3 & 450 & 7,5 \\
$\mathrm{~A}_{2}$ & 27,5 & 1,5 & 48 & 1,7 & 500 & 5,5 \\
$\mathrm{~A}_{3}$ & 29 & 1,5 & 39 & 2,1 & 350 & 8,5 \\
$\mathrm{~A}_{4}$ & 25,5 & 1 & 42 & 2,4 & 500 & 8 \\
$\mathrm{~A}_{5}$ & 19 & 2 & 40 & 2 & 450 & 9,2 \\
\hline
\end{tabular}


Here is a solution by applying the COPRAS method:

The first step creates a decision matrix based on table 2, below.

$X i j=\left[\begin{array}{llllll}22,5 & 2 & 35 & 1,3 & 450 & 7,5 \\ 27,5 & 1,5 & 48 & 1,7 & 500 & 5,5 \\ 29 & 1,5 & 39 & 2,1 & 350 & 8,5 \\ 25,5 & 1 & 42 & 2,4 & 500 & 8 \\ 19 & 2 & 40 & 2 & 450 & 9,2\end{array}\right]$

The second step normalizes from the $\mathrm{x}_{\mathrm{ij}}$ decision matrix. To create a decision matrix using equation 2.

$$
\begin{array}{ll}
\mathrm{C}_{1}=(22,5+27,5+29+25,5+19)=123,5 & \mathrm{C}_{2}=(2+1,5+1,5+1+2)=8 \\
\mathrm{~A}_{11}=22,5: 123,5=0,182 & \mathrm{~A}_{12}=2: 8=0,250 \\
\mathrm{~A}_{21}=27,5: 123,5=0,223 & \mathrm{~A}_{22}=1,5: 8=0,188 \\
\mathrm{~A}_{31}=29: 123,5=0,235 & \mathrm{~A}_{32}=1,5: 8=0,188 \\
\mathrm{~A}_{41}=25,5: 123,5=0,206 & \mathrm{~A}_{42}=1: 8=0,125 \\
\mathrm{~A}_{51}=19: 123,5=0,154 & \mathrm{~A}_{52}=2: 8=0,250 \\
& \\
\mathrm{C}_{3}=(35+48+39+42+40)=204 & \mathrm{C}_{4}=(1,3+1,7+2,1+2,4+2)=9,5 \\
\mathrm{~A}_{13}=35: 204=0,172 & \mathrm{~A}_{14}=1,3: 9,5=0,137 \\
\mathrm{~A}_{23}=48: 204=0,235 & \mathrm{~A}_{24}=1,7: 9,5=0,179 \\
\mathrm{~A}_{33}=39: 204=0,191 & \mathrm{~A}_{34}=2,1: 9,5=0,221 \\
\mathrm{~A}_{43}=42: 204=0,206 & \mathrm{~A}_{44}=2,4: 9,5=0,253 \\
\mathrm{~A}_{53}=40: 204=0,196 & \mathrm{~A}_{55}=2: 9,5=0,211 \\
& \\
C_{5}=(450+500+350+500+450)=2250 & \mathrm{C}_{6}=(7,5+5,5+8,5+8+9,2)=38,7 \\
\mathrm{~A}_{15}=450: 2250=0,200 & \mathrm{~A}_{16}=7,5: 38,7=0,194 \\
\mathrm{~A}_{25}=500: 2250=0,222 & \mathrm{~A}_{26}=5,5: 38,7=0,142 \\
\mathrm{~A}_{35}=350: 2250=0,156 & \mathrm{~A}_{36}=8,5: 38,7=0,220 \\
\mathrm{~A}_{45}=500: 2250=0,222 & \mathrm{~A}_{46}=8: 38,7=0,207 \\
\mathrm{~A}_{55}=450: 2250=0,200 & \mathrm{~A}_{56}=9,2: 38,7=0,238
\end{array}
$$

The above calculation will produce a normalized matrix, as follows:

$$
X i j=\left[\begin{array}{llllll}
0,182 & 0,250 & 0,172 & 0,137 & 0,200 & 0,194 \\
0,223 & 0,188 & 0,235 & 0,179 & 0,222 & 0,142 \\
0,235 & 0,188 & 0,191 & 0,221 & 0,156 & 0,220 \\
0,206 & 0,125 & 0,206 & 0,253 & 0,222 & 0,207 \\
0,154 & 0,250 & 0,196 & 0,211 & 0,200 & 0,238
\end{array}\right]
$$

The third step uses equation 3 to calculate the weighted normalization matrix.

$$
\begin{array}{ll}
\mathrm{D}_{11}=0,182 * 0,25=0.0421 & \mathrm{D}_{14}=0,137 * 0,25=0.117 \\
\mathrm{D}_{21}=0,223 * 0,25=0.0421 & \mathrm{D}_{24}=0,179 * 0,25=0.117
\end{array}
$$




$$
\begin{array}{ll}
\mathrm{D}_{31}=0,235 * 0,25=0.0315 & \mathrm{D}_{34}=0,221 * 0,25=0.023 \\
\mathrm{D}_{41}=0,206 * 0,25=0.0315 & \mathrm{D}_{44}=0,253 * 0,25=0.023 \\
\mathrm{D}_{51}=0,154 * 0,25=0.0526 & \mathrm{D}_{54}=0,211 * 0,25=0.0117 \\
\mathrm{D}_{12}=0,250 * 0,15=0.0421 & \mathrm{D}_{15}=0,200 * 0,15=0.23 \\
\mathrm{D}_{22}=0,188 * 0,15=0.0421 & \mathrm{D}_{25}=0,222 * 0,15=0.04 \\
\mathrm{D}_{32}=0,188 * 0,15=0.0421 & \mathrm{D}_{35}=0,156 * 0,15=0.023 \\
\mathrm{D}_{42}=0,125 * 0,15=0.0210 & \mathrm{D}_{45}=0,222 * 0,15=0.023 \\
\mathrm{D}_{52}=0,250 * 0,15=0.0526 & \mathrm{D}_{55}=0,200 * 0,15=0.023 \\
\mathrm{D}_{13}=0,172 * 0,10=0.02 & \mathrm{D}_{16}=0,194 * 0,10=0.23 \\
\mathrm{D}_{23}=0,235 * 0,10=0.02 & \mathrm{D}_{26}=0,142 * 0,10=0.04 \\
\mathrm{D}_{33}=0,191 * 0,10=0.006 & \mathrm{D}_{36}=0,220 * 0,10=0.023 \\
\mathrm{D}_{43}=0,206 * 0,10=0.02 & \mathrm{D}_{46}=0,207 * 0,10=0.023 \\
\mathrm{D}_{53}=0,196 * 0,10=0.03 & \mathrm{D}_{56}=0,238 * 0,10=0.023
\end{array}
$$

Then the matrix D will be formed as follows:

$$
D i j=\left[\begin{array}{llllll}
0,046 & 0,038 & 0,017 & 0,034 & 0,030 & 0,019 \\
0,056 & 0,028 & 0,024 & 0,045 & 0,033 & 0,014 \\
0,059 & 0,028 & 0,019 & 0,055 & 0,023 & 0,022 \\
0,052 & 0,019 & 0,021 & 0,063 & 0,033 & 0,021 \\
0,038 & 0,038 & 0,020 & 0,053 & 0,030 & 0,024
\end{array}\right]
$$

The fourth step counts the number of beneficial criteria and the number of cost criteria.

The number of benefit: criteria:

$$
\begin{aligned}
& S_{+1}=0,034+0,030+0,019=0,0836 \\
& S_{+2}=0,045+0,033+0,014=0,0923 \\
& S_{+3}=0,055+0,023+0,022=0,1006 \\
& S_{+4}=0,063+0,033+0,021=0,1172 \\
& S_{+5}=0,053+0,030+0,024=0,1064
\end{aligned}
$$

The number of cost criteria:

$$
\begin{aligned}
& S_{-1}=0,046+0,038+0,017=0,1002 \\
& S_{-2}=0,056+0,028+0,024=0,1073 \\
& S_{-3}=0,059+0,028+0,019=0,1059 \\
& S_{-4}=0,052+0,019+0,021=0,0910 \\
& S_{-5}=0,038+0,038+0,020=0,0956
\end{aligned}
$$

The sum of the deducing criteria: 0,500

The fifth step calculates the relative weights of each alternative using equation 6 . In table 3 it is a calculation of the total of the $S_{-i}$ values.

Table 3: Total $\mathrm{S}_{-\mathrm{i}}$

\begin{tabular}{c}
\hline $1 / \mathrm{S}_{-\mathrm{i}}$ \\
\hline $1 / 0,1002=9,980$ \\
$1 / 0,1073=9,318$ \\
$1 / 0,1059=9,439$ \\
$1 / 0,0910=10,994$ \\
$1 / 0,0956=10,464$ \\
\hline
\end{tabular}




$$
\begin{aligned}
& \text { Calculation to get } \mathrm{Q}_{\mathrm{i}}: \\
& \mathrm{Q}_{1}=0,0836+(0,500 /(0,1002 * 50,194))=0,18 \\
& \mathrm{Q}_{2}=0,0923+(0,500 /(0,1073 * 50,194))=0,19 \\
& \mathrm{Q}_{3}=0,1006+(0,500 /(0,1059 * 50,194))=0,19 \\
& \mathrm{Q}_{4}=0,1172+(0,500 /(0,0910 * 50,194))=0,23 \\
& \mathrm{Q}_{5}=0,1064+(0,500 /(0,0956 * 50,194))=0,21 \\
& \operatorname{Max}\left(\mathrm{Q}_{\mathrm{i}}\right)=0,23
\end{aligned}
$$

The last step is calculate of quantitative utility $\left(\mathrm{U}_{\mathrm{i}}\right)$ value for each alternative.

$$
\begin{aligned}
& \mathrm{U}_{1}=(0,18 / 0,23) * 100=80,73 \% \\
& \mathrm{U}_{2}=(0,19 / 0,23) * 100=81,66 \% \\
& \mathrm{U}_{3}=(0,19 / 0,23) * 100=85,84 \% \\
& \mathrm{U}_{4}=(0,23 / 0,23) * 100=100,0 \% \\
& \mathrm{U}_{5}=(0,21 / 0,23) * 100=92,92 \%
\end{aligned}
$$

Table 4: Results of Quantitative Utility $\left(\mathrm{U}_{\mathrm{i}}\right)$

\begin{tabular}{ccc}
\hline Alternative & $\mathrm{U}_{\mathrm{i}}$ & Rank \\
\hline $\mathrm{A}_{4}$ & $100,0 \%$ & 1 \\
$\mathrm{~A}_{5}$ & $92,92 \%$ & 2 \\
$\mathrm{~A}_{3}$ & $85,84 \%$ & 3 \\
$\mathrm{~A}_{2}$ & $81,66 \%$ & 4 \\
$\mathrm{~A}_{1}$ & $80,73 \%$ & 5 \\
\hline
\end{tabular}

The final result of calculation above, then $A_{4}>A_{5}>A_{3}>A_{2}>A_{1}$, where $A_{4}$ is $100 \%, A_{5}$ is $92,92 \%, A_{3}$ is $85,84 \%, A_{2}$ is $81,66 \%$ and $A_{1}$ is $80,73 \%$. So that $A_{4}$ is the best alternative and has priority in getting cooperative loan fund.

\section{Conclusion}

From the discussion to determine the recipients of cooperative loan funds above, it can be concluded, as follows:

1. Both positive and negative criteria have a calculation process affecting each utility level of each alternative that will get cooperative loan funds.

2. The process in the calculation of negative criteria (less favorable) is done more complex when compared with positive (favorable) criterion, in this case, the criterion of negative criterion evaluated from each alternative that exists.

3. Use of COPRAS method applied to the calculation process in decision support system can assist the cooperative in determining the members who are entitled to get cooperative loan funds more effectively and is expected to avoid failure of members in paying off the credit.

\section{Reference}

[1] D. Siregar, D. Arisandi, A. Usman, D. Irwan, and R. Rahim, "Research of Simple MultiAttribute Rating Technique for Decision Support," J. Phys. Conf. Ser., vol. 930, no. 1, p. 012015, Dec. 2017.

[2] Mesran, P. Ramadhani, A. Nasution, D. Siregar, Fadlina, and A. P. U. Siahaan, 
"Implementation of Complex Proportional Assessment Method in the Selection of Mango Seeds," Int. J. Sci. Res. Sci. Technol., vol. 3, no. 7, pp. 397-402, 2017.

[3] R. Rahim, Mesran, A. Putera, U. Siahaan, and S. Aryza, "Composite performance index for student admission,” Int. J. Res. Sci. Eng., vol. 3, no. 3, pp. 68-74, 2017.

[4] R. Attri and S. Grover, "Application of preference selection index method for decision making over the design stage of production system life cycle," J. King Saud Univ. - Eng. Sci., vol. 27, no. 2, pp. 207-216, 2015.

[5] R. Khorshidi and A. Hassani, "Comparative analysis between TOPSIS and PSI methods of materials selection to achieve a desirable combination of strength and workability in $\mathrm{Al} / \mathrm{SiC}$ composite," Mater. Des., vol. 52, no. June, pp. 999-1010, 2013.

[6] J. Papathanasiou, N. P. B, T. Bournaris, and B. Manos, "A Decision Support System for Multiple Criteria Alternative Ranking Using TOPSIS and VIKOR: A Case Study on Social Sustainability in Agriculture," ICDSST, vol. 2, pp. 3-15, 2016.

[7] Kusrini., Konsep dan aplikasi Sistem Pendukung Keputusan. Andi. Yogyakarta: Andi The publishing company, 2007.

[8] T.-P. Turban, E., Aronson, J., \& Liang, Decision Support Systems And Inteligence System. US: Prentice-Hall, 2005

[9] P. harliana and R. Rahim, "Comparative Analysis of Membership Function on Mamdani Fuzzy Inference System for Decision Making," J. Phys. Conf. Ser., vol. 930, no. 1, p. 012029, Dec. 2017.

[10] R. Rahim, S. Nurarif, M. Ramadhan, S. Aisyah, and W. Purba, "Comparison Searching Process of Linear, Binary and Interpolation Algorithm,” J. Phys. Conf. Ser., vol. 930, no. 1, p. 012007 , Dec. 2017.

[11] C.-L. Yoon, K.P., \& Hwang, "Multiple Attribute Decision Making: An Introduction," Sage Univ. Pap. Ser. Quantative Appl. Soc. Sci., pp. 47-53, 1995.

[12] S. Kusumadewi, S. Hartati, A. Harjoko, and R. Wardoyo, Fuzzy Multi-Attribute Decision Making (Fuzzy MADM). Yogyakarta: Graha Ilmu, 2006.

[13] M. Behzadian, R. B. Kazemzadeh, A. Albadvi, and M. Aghdasi, "PROMETHEE: A comprehensive literature review on methodologies and applications," Eur. J. Oper. Res., vol. 200, no. 1, pp. 198-215, 2010.

[14] J. Jasri, D. Siregar, and R. Rahim, "Decision Support System Best Employee Assessments with Technique for Order of Preference by Similarity to Ideal Solution," Int. J. Recent Trends Eng. Res., vol. 3, no. 3, pp. 6-17, Mar. 2017.

[15] Y. Silalahi, Mesran, T. Zebua, and Suginam, "PENERAPAN THE EXTENDED PROMETHEE II ( EXPROM II ) UNTUK PENENTUAN PRODUK DISKON," KOMIK (Konferensi Nas. Teknol. Inf. dan Komputer), vol. I, no. 1, 2017.

[16] Fadlina, L. T. Sianturi, A. Karim, Mesran, and A. P. U. Siahaan, "Best Student Selection Using Extended Promethee II Method," Int. J. Recent Trends Eng. Res., vol. 3, no. 8, pp. 21-29, 2017.

[17] Esra; and AyG̣egül, "AIR CONDITIONER SELECTION PROBLEM WITH COPRAS AND ARAS METHODS,” Manas J. Soc. Stud., vol. 5, no. 2, 2016.

[18] P. Chatterjee and S. Chakraborty, "Flexible manufacturing system selection using preference ranking methods: A comparative study," Int. J. Ind. Eng. Comput., vol. 5, no. 2, pp. 315-338, 2014.

[19] E. Y. Ress., "Performance Evaluation Of Research Assistants By Copras Method," Eur. Sci. J., pp. 102-109, 2016. 